INFLUENCE OF DISCLOSURE CORPORATE SOCIAL RESPONSIBILITY

TOWARD SUSTAINABLE ECONOMIC DEVELOPMENT WITH FINANCIAL

PERFORMANCE AS AN INTERVENING VARIABLE

\title{
INFLUENCE OF DISCLOSURE CORPORATE SOCIAL RESPONSIBILITY TOWARD SUSTAINABLE ECONOMIC DEVELOPMENT WITH FINANCIAL PERFORMANCE AS AN INTERVENING VARIABLE
}

(Empirical Study of Mining Companies Listed on the List of Islamic Securities Years 2016-2018)

\author{
Muhammad Faizul Mamduh ${ }^{1}$, Ratno Agriyanto ${ }^{2}$, Dessy Noor Farida ${ }^{3}$ \\ ${ }^{1,2,3}$ Faculty of Economics and Islamic Business, Walisongo State Islamic University
}

\begin{abstract}
Companies in carrying out their business have obligations to stakeholders in any form. CSR is one of the company's responsibilities for the activities carried out so far to the surrounding environment. In reality the CSR program has not been able to speak much in helping to improve the welfare of the community through sustainable development. This can be seen from the percentage of poverty in Indonesia that is still quite high. BPS noted that the highest poverty rate was in eastern Indonesia, namely the islands of Maluku and Papua with a percentage of $21.45 \%$. This study aims to determine the effect of corporate social responsibility disclosure on sustainable economic development with financial performance as an intervening variable (an empirical study of mining companies listed on the 2016-2018 Syariah Securities List). The method used in this study is a quantitative method using the Warp PLS 4.0 application. The results of this study state that there is a significant influence and positive relationship between corporate social responsibility and sustainable economic development. There is a significant influence and positive relationship between corporate social responsibility and financial performance. And financial performance as an intervening variable significantly and positively influences between corporate social responsibility and sustainable economic development.
\end{abstract}

Keywords: corporate social responsibility, sustainable economic development, and financial performance.

\section{INTRODUCTION}

Existence of the company in the midst of the rampant issue of CSR that is widely discussed and received attention from many circles because there are many misconceptions about the conception of CSR. That happened because the Constitutional Court (MK) at that time refused a number of business associations and companies to revoke Article 74 of Law No.40 of 2007 concerning Limited Liability Companies (UUPT), CSR was the company's obligation. Not only in Indonesia, CSR has also become a global issue that has received attention from market leaders and leaders of state institutions at the United Nations.

*Corresponding author. Email address: faizfama16@gmail.com 


\section{AFEBI Islamic Finance and Economic Review (AIFER)}

\section{Vol.3 No.2, December 2018}

The emergence of the Global Compact, Global Reporting Initiatives (GRI), and ISO 26000 on CSR shows that CSR becomes a crucial issue and a global business agenda that must receive serious attention from business people and the business world (Lako, 2011).

In the implementation of the implementation of CSR in Indonesia is still far from optimal in the use of funds. Quoted from kompas.com Indonesian Chamber of Commerce and Industry (Kadin) assesses the need for the government's active role in the use of CSR funds so that the money spent can be right on target. It was revealed that CSR funds are considered as excess money for companies that are thrown away for regional governments, without knowing what they are used for. Deputy Chairperson of the Indonesian Chamber of Commerce and Industry, Benny Soetrisno, said that the government asked the company's CSR not only in the form of barracks assistance and there needs to be synergy between Kadin, the local government and NGOs in the field of CSR. company. Quoted from kompas.com Former Deputy Governor of DKI Jakarta Sandiaga Uno said, many programs in the form of corporate social responsibility or CSR are actually used to portray the company, it is actually not CSR but advertising (Putra, 2017). Companies that take advantage of these conditions are certainly not in line with the objectives set by CSR that function for community development in the economic, social and environmental spheres.

The world also responded in this regard with the existence of Sustainable Development Goals (SDGs) which were ratified at the United Nations general meeting on 25 September 2015 in New York. The SDGs contain 17 development goals and 169 goals that are expected to answer the underdeveloped development of countries around the world. This is in line with the concept of CSR that was agreed upon in the World Summit on Sustainable Development (WS-SD) in Johannesburg, South Africa in 2002 aimed at encouraging all companies in the world in order to create a sustainable development. The role of CSR can be seen as an effort to create good corporate governance, good corporate citienship and good business ethics of a business entity (Andi, 2009).

Research conducted by the United Nations shows that approximately 1,000 CEOs from more than 100 countries conclude that around $89 \%$ of CEOs have realized that the company's commitment to the SDGs can have an impact on their industry. PWC researched in 2017, out of 470 companies in 17 countries, found that $62 \%$ of companies in the world had included SDGs in company reports. However, only $37 \%$ are serious in establishing the SDGs target as a priority for the company. And the rest, which is $63 \%$ of companies do not include a link between SDGs and company targets in the company report (Farida, 2019). This proves that the company leaders are only aware without giving a real implication on the application of SDGs in the scope of exploitation.

Indonesia is an archipelago country with a very wide area and has abundant natural wealth, of course many investors are investing their capital in 
INFLUENCE OF DISCLOSURE CORPORATE SOCIAL RESPONSIBILITY TOWARD SUSTAINABLE ECONOMIC DEVELOPMENT WITH FINANCIAL PERFORMANCE AS AN INTERVENING VARIABLE

Indonesia. Many companies stand in Indonesia from various sectors to utilize natural resources in Indonesia, both domestic and foreign companies. Quoted from Republika.com, most companies in Indonesia have high financial performance, so they can play a role in the realization of Non-Tax State Revenues. Even the media from the United States Forbes released there are 200 companies in Asia that get profits above 1 billion US dollars and 11 companies from Indonesia are included in the list. PT Adaro Energy Tbk is one of them, over the past 5 years based on accumulative RTI, Adaro recorded a profit growth of $24.37 \%$ and net income over the past 5 years grew $112.1 \%$. Forbes noted, Adaro earned a profit of 2.9 billion US dollars with a total assets of 4.5 billion US dollars (Wulandari \& Yolanda, 2019).

The condition of companies in Indonesia with very high profits is inversely proportional to the percentage of fisheries in Indonesia that is still quite high. BPS recorded that as of March 2017 the percentage of poverty has averaged above $10 \%$ based on the islands. The percentage of poverty in Java is $10.01 \%$, Sumatra $10.97 \%$, Bali and Nusa Tenggara $14.71 \%$, Sulawesi $11.05 \%$, Maluku and Papua $21.45 \%$ and Kalimantan $6.25 \%$ (Rachman, 2017). These figures indicate that poverty levels in Indonesia are still quite high. In addition to government policies as an effort to reduce poverty, the role of companies that have operational activities in the territory of Indonesia also plays an important role in this regard. CSR programs as a form of corporate concern for the environment and surrounding communities over operational activities are certainly one of the ways in supporting poverty alleviation, sustainable development and realizing SDGs. The synergy of companies and policy makers in this case the government is needed in realizing all the objectives that have been listed. Companies get legality in carrying out operational activities of their companies and the government indirectly helped by the existence of the CSR program.

The triple bottom line concept (profit, planet, people) initiated by John Elkington provides an explanation that CSR is not only a program that benefits companies but also benefits the environment and society. (Husnan, 2013) This research is based on previous research conducted by (Wahyuningrum, Noor, \& Wachid, 2014) who said that there was a significant influence between CSR and community empowerment and research conducted by (Retnaningsih, 2015) which revealed that the concept of CSR was good, but unfortunately until now many companies have not implemented it well. The difference between this study and previous research is by using financial performance as an intervening variable that has not been done much by previous researchers.

\section{LITERATURE STUDY AND HYPOTHESIS DEVELOPMENT Legitimacy Theory}

The legitimacy theory provides an explanation that the influence of society at large can determine the allocation of financial resources and other economic resources, companies tend to use environmental-based performance and 


\section{AFEBI Islamic Finance and Economic Review (AIFER)}

\section{Vol.3 No.2, December 2018}

disclosure of environmental information to justify or legitimize company activities in the eyes of the public. Furthermore Dowling and Pfeffer said: "Legitimacy is important for the organization, the limits are emphasized by social norms and values, the reaction to these limits encourages the importance of organizational behavior analysis with regard to the environment". Meanwhile Ghozali and Chariri explained that what underlies the theory of legitimacy is the social contract that takes place between the company and the community in which the company operates and uses economic resources. Explanation of the concept of social contract was revealed by Shocker and Sethi: "All social institutions are no exception companies that operate in the community through explicit or implicit social contracts in which their survival and growth are based on the final output (output) that can be given socially to the community that the extent and distribution of economic, social or political benefits to groups according to their strength " (Husnan, 2013).

\section{Corporate Social Responsibility}

CSR according to ISO 26000 is the responsibility of an organization for the impacts of decisions and activities on society and the environment which is manifested in the form of transparent and ethical behavior that is in line with sustainable development and public welfare taking into account stakeholder expectations, in line with established laws and norms. international norms of behavior, and integrated with the organization as a whole (Wardhani, 2013).

The entire implementation of social responsibility that has been carried out by the company will be socialized to the public one of them through social disclosure in the annual report (annual report) issued by the company. The annual report provides an overview of the company's comprehensive performance in terms of financial information and non-financial information that needs to be known by shareholders, potential investors, the government or even the public. Therefore, disclosure of information made by the company in the annual report becomes one of the considerations for investors to invest in the company concerned. The purpose of financial statements is to report the activities of companies that affect the community, which can be determined and explained or measured, and important for the company in its social environment. (Arifin \& Wardani, 2016).

According to Wardhani, CSR is a balanced approach for organizations to address economic, social and environmental issues in ways that benefit individuals and society. Over the past decade, many countries have given importance to this concept to deal with issues concerning unemployment, poverty, pollution and other social and environmental problems. Furthermore, the recent financial crisis has drawn widespread attention to the socioeconomic dimension in finance and banking. Then, it is now agreed that the lack of ethics and low 
INFLUENCE OF DISCLOSURE CORPORATE SOCIAL RESPONSIBILITY TOWARD SUSTAINABLE ECONOMIC DEVELOPMENT WITH FINANCIAL PERFORMANCE AS AN INTERVENING VARIABLE

business morality hasconsequences damageable that not only occur in finance, but also socially and environmentally (Wardhani, 2013).

\section{Sustainable Development}

Sustainable development was popularized through the World Commission on Environment and Development report in 1987. The sustainability perspective is defined as the capacity for renewal and evolution in ecosystems, as well as innovation and creativity in social systems. This concept arises from a mutual agreement between commission members, that many development activities result in poverty and deterioration as well as environmental damage, so that new paths for development that bring progress to humans should not only be made for a short time but for a longer period of time (Adharani, 2017).

In Indonesia, the term sustainable development is officially included in Law No.4 of 1982 concerning Environmental Principals article 1 paragraph 3 of the PPLH Law: Sustainable development is a conscious and planned effort that integrates environmental, social, and economic aspects into a development strategy for guarantee the integrity of the environment as well as the safety, ability, welfare, and quality of life of present and future generations (Helmi, 2011).

Two key concepts that are rarely cited are that sustainable development is related to the first, human needs in developing countries to meet their needs and secondly, the limitations of technology and social organization relating to environmental capacity to meet the needs of present and future generations. This results in different emphases in sustainable development in developed and developing countries. Developing countries give priority to sustainable development in meeting the basic human needs at the moment, as well as ensuring the sustainability of economic development. This emphasis places integrated economic and environmental considerations as a sustainable development strategy (Adharani, 2017).

\section{Financial Performance}

According to the Decree of the Minister of Finance No. 740 / KMK.00 / 1989 dated June 28, 1989, what is meant by performance is the achievement achieved by the company in a certain period that reflects the level of health of the company. Performance bank as a whole is a picture of the achievements of the bank in its operations, both related to financial aspects, marketing, collection and distribution of funds, technology and human resources (Sulhan \& Halimah, 2013).

Financial performance is a determination of certain measures that can measure the success of a company in generating profits. In measuring financial performance, it is necessary to link the company with the responsibility center. Financial performance appraisal is one of the ways undertaken by management in order to fulfill its obligations to the owners of the company. In evaluating financial performance, of course, it requires certain standards, both external and internal. 


\section{AFEBI Islamic Finance and Economic Review (AIFER)}

\section{Vol.3 No.2, December 2018}

External standards refer to competitive benchmarking which is a comparison of companies with major competitors or industry. Company evaluations that refer to external standards through competitive benchmarks provide ideas for developing an analysis of individual company financial ratios by considering industry ratios (Husnan, 2013).

In other literatures the performance appraisal of each company is different because it depends on the scope of the business it runs. If the company is engaged in the mining business sector, it is different from companies engaged in agriculture and fisheries. So it is also the case with companies with financial sectors such as banking which clearly have different business scope with other business scopes, because as we know, banking is a mediation that connects those who have excess funds (financial surplus) with those who have lack of funds (financial deficits ), and the bank's duty is to bridge the two (Fahmi, 2017).

\section{Hypothesis Development}

\section{Effect of Disclosure Corporate Social Responsibility on Sustainable Economic Development}

CSR is a company's social responsibility to stakeholders consisting of $3 \mathrm{P}$ (Profit, People, Planet). In essence, CSR is how a company has responsibility for the welfare of the people (people) and environmental sustainability (the planet) around them while still not forgetting to take into account the profits long-term to be gained. CSR itself is regulated in Law No. 40 of 2007 concerning limited liability companies, the obligation to grant CSR is only limited to companies or companies whose business activities are related to Natural Resources (SDA). According to Kim, the company's CSR practices can be identified in a variety of objectives, namely law, economics, morals, and philanthropy. However, these goals can still be developed in accordance with the actual conditions in society related to the pressures that occur in community life. One of the CSR goals that is very urgent, especially in developing countries, is to improve the quality of public education. Therefore the application of CSR in Indonesia basically can be directed at strengthening the people's economy based on small and medium-sized businesses and improving the quality of community human resources through the improvement of educational facilities and infrastructure (Andi, 2009).

Brundtland explains sustainable development as follows: "Sustainable development is the development that meets the needs of the present without compromising the ability of future generations to meet their own needs." This means that sustainable development is development that is in line with the needs of future generations. John McMurty, a philosopher explained that sustainable development is related to the development of civil commons, general needs, where everyone in the community can access the necessities of life, so that everyone can develop and express themselves as human beings. These general 
INFLUENCE OF DISCLOSURE CORPORATE SOCIAL RESPONSIBILITY TOWARD SUSTAINABLE ECONOMIC DEVELOPMENT WITH FINANCIAL PERFORMANCE AS AN INTERVENING VARIABLE

needs include public education, health, environmental legality, health and safety regulations, and general broadcasts (Suparno, 2012).

The description above can be explained that the company has obligations to the environment and the community for its activities that utilize natural resources and are carried out in the form of CSR. CSR programs run by companies must have an impact on the survival of the community and the surrounding environment. Expectations from the implementation of CSR will be prioritized to strengthen the economy and improve the quality of human resources which will later become the foundation in implementing sustainable development.

According to the research of (Wahyuningrum, Noor, \& Wachid, 2014) CSR has a significant and simultaneous significant effect between social, economic and environmental variables on increasing community empowerment. In another study conducted by (Setyaningrum, 2011), it was shown that showed that all variables used, namely the Corporate Social Responsibility Goal, Corporate Social Issues, and the Corporate Social Program had a significant positive effect on improving the welfare of the community. Based on the description, the researcher took the following hypothesis:

H1 : CSR disclosure has a significant effect on Sustainable Economic Development

\section{Effects of Disclosure Corporate Social Responsibility on Financial Performance}

Measures commonly used to assess company performance are expressed in financial ratios. The ability of a company to generate profits in its operations (profitability) is the main focus in evaluating company performance because corporate profits are not only an indicator of a company's ability to meet obligations for funders as well as an element in value creation company that shows the company's prospects in the future. The level of profitability can be used as a basis for investment decision making to measure a company's ability to produce a rate of return on investments made.

Deegan highlighted that CSR has become an driver important in influencing the opinions of stakeholders regarding the fulfillment of company obligations. Maignan points out that stakeholders refer to those who directly or indirectly influence or are influenced by company activities. In communicating activities CSR, many companies use their annual reports as disclosure media. (Arifin \& Wardani, 2016)

According to Ahmad Husnan's research (2013), the results of testing show that CSR has a significant effect on Return on Assets (ROA), but does not have a significant effect on Return on Equity (ROE). This explains that if the company implements a CSR program, it will attract investors to invest in the company and add value to the company's assets. Based on the description above, the researcher takes the following hypothesis: 


\section{AFEBI Islamic Finance and Economic Review (AIFER)}

\section{Vol.3 No.2, December 2018}

H2 :Disclosure Corporate social responsibility has a significant effect on financial performance

Effects of Disclosure Corporate Social Responsibility on Sustainable Economic Development Through financial performance

Corporate social responsibility (CSR) is currently a concept that is often heard, although the definition itself is still a debate among practitioners and academics. CSR is considered by the company to increase the burden and reduce the profit company's. CSR programs made by the company become a long-term investment that is expected to increase profits company.

According to the theory of legitimacy that there is an interaction between the company and the community. Dowling and Prefer provide logical reasons for the legitimacy of the organization as follows:

"The organization seeks to create harmony between social values inherent in its activities with the norms of behavior that exist in the social system of society where the organization is part of the system. As long as the two value systems are aligned, we can see this as the company's legitimacy. When actual and potential inconsistencies occur between the two systems, there is a threat to the legitimacy of the company (Husnan, 2013).

CSR disclosure in a company is a disclosure of environmental, social, and economic performance in annual financial reports or selected reports reflecting accountability, responsibility, and transparency corporate to investors and stakeholders other. The disclosure has a good and effective communication relationship between the company, the public, and stakeholders other about how the company has integrated corporate responsibility social environmental in every aspect of its operations. In a study conducted by Rulyanti Susi Wardhani (2013) resulted that the effect of CSR disclosure on company value through financial performance and going concern value had a positive and significant effect (Wardhani, 2013). From the description, the researchers formulated the hypothesis:

$\mathrm{H} 3$ : financial performance as an intervening variable has a positive and significant effect between disclosure corporate social responsibility and sustainable economic development

\section{RESEARCH METHODOLOGY}

This research is an empirical study using Warp PLS 4.0 software with outer models, inner models and hypothesis testing (Abdillah \& Hartono, 2015). Which test examines the relationship between disclosure corporate social responsibility on sustainable economic development and financial performance as an intervening variable.

Population, Samples and Sampling Techniques 
INFLUENCE OF DISCLOSURE CORPORATE SOCIAL RESPONSIBILITY TOWARD SUSTAINABLE ECONOMIC DEVELOPMENT WITH FINANCIAL PERFORMANCE AS AN INTERVENING VARIABLE

The population of this study is mining companies registered in the List of Sharia Securities (DES). While the sample is a mining company listing in DES 3 years in a row from 2016-2018. The sampling method by purposive sampling with the criteria determined as follows:

a. Companies that are consistently registered in DES in 2016-2018

b. Companies that publish annual reports in 2016-2018

c. Companies that get an unqualified opinion from independent auditors during 2016-2018

d. Companies whose exploitation areas are in Kalimantan Island

\section{Operational Definition and Measurement of Variables} Corporate Social Responsibility (CSR)

Information about Corporate Social Responsibility based on GRI (Global Reporting Initiative) standards. GRI consists of 3 disclosure focuses (Mubarok, 2013) namely:

a. Economy

The economic dimension concerns the sustainability of an organization that impacts the economic conditions of stakeholders and the economic system at the local, national and global levels. Economic indicators describe:

- Capital flows among the various stakeholders, and

- The main economic impact of the whole community organization.

Financial performance is fundamental to understanding the organization and its sustainability. However, this information is usually already reported in the financial statements.

b. Environment

The environmental dimension concerns the sustainability of an organization's impact on life in natural systems, including ecosystems, soil, air, and water. Environmental performance indicators are related to inputs (materials, energy, water) and outputs (emissions / gas, river waste, dry waste / garbage). In addition, their performance includes performance related to biodiversity, environmental compliance, and other relevant information such as environmental waste and the impact of products and services.

c. Social

The social dimension concerning the sustainability of an organization has had an impact on the social system that operates. GRI's social performance indicators identify key aspects of performance that include labor / labor practices, human rights, community / social, and product responsibilities.

The CSRI calculation uses a dichotomous approach in which each CSRI item is given a value of 1 if disclosed, and a value of 0 if not disclosed. Each item will add up to get the overall company score (Rakhiemah \& Agustia, 2009). 


\section{AFEBI Islamic Finance and Economic Review (AIFER)}

\section{Vol.3 No.2, December 2018}

CSR is calculated using the formula: $\operatorname{CSRIj}=\sum \frac{X i j}{n j}$

Description:

CSRIj : Corporate Corporate Responsibility Disclosure Index j

$\mathrm{Nj} \quad$ : Number of items for company $\mathrm{j}, \mathrm{nj} \leq 78$

$\mathrm{Xij} \quad$ : Dummy Variable: $1=$ if item $\mathrm{j}$ was disclosed; $0=$ if the item was not disclosed (Mertasari \& Suaryana, 2013)

Index CSR disclosure by standard GRI (Global Reporting Initiative), as follows:

a) Indicators of Economic Performance (economic performance indicator)

b) Performance Indicators Environment (environment performance indicator)

c) Performance Indicators of Labor (labor practices performance indicators)

d) Human Rights performance indicators (human rights performance indicator)

e) Social performance indicators (social performance indicators)

f) Product Performance Indicators (product responsibility performance indicators)

\section{Sustainable Economic Development}

Sustainable development is sustainable development popularized through the World Commission's report on Environment and Development in 1987. The perspective of sustainability is defined as the capacity for renewal and evolution in ecosystems, as well as innovation and creativity in social systems. For this research, sustainable development is measured from community empowerment using the level of education and health level of the local community. Taking these indicators is based on previous research that only uses 2 indicators.

According to Law No. 36 of 2009 on Health it is explained that health efforts are every activity and / or series of activities carried out in an integrated, integrated and continuous manner to maintain and improve the degree of public health in the form of disease prevention, health promotion, treatment of diseases and health recovery and / or the community. Therefore the indicators taken from the health level are the percentage of children aged 12-23 months who received basic immunization complete with the lowest $40 \%$ welfare rate and the percentage of households that have access to proper and sustainable sanitation services (lower 40\%).

The understanding of education according to Presidential Instruction No. 15 of 1974 is all efforts to foster the personality and develop the ability of Indonesian people, physically and spiritually which lasts a lifetime, both 
INFLUENCE OF DISCLOSURE CORPORATE SOCIAL RESPONSIBILITY TOWARD SUSTAINABLE ECONOMIC DEVELOPMENT WITH FINANCIAL PERFORMANCE AS AN INTERVENING VARIABLE

inside and outside the school in the context of building the unity of Indonesia and a just, prosperous society based on Pancasila. Measurement of education level from this study is taken from the indicators of the Pure Participation Rate (APM) of SMA / MA / Equals (40\% and below) and Literacy Rate (AMH) for Population aged 15 Years and Over.

\section{Financial Performance}

Measurement of financial performance can be done by assessing financial ratio analysis. Financial ratio analysis is the basis for assessing and analyzing company operating achievements or company performance. Financial ratios are designed to evaluate financial statements, which contain data about the company's position at a point and the company's past operations. Analysis of financial statements is the beginning of the future when viewed from the perspective of investors, while for management, it is useful to help anticipate future conditions and become a starting point for planning actions that will affect the course of future events. The variables in this study are the company's financial performance represented by ROA, and ROE.

Mathematically ROA can be formulated as follows:

$$
R O A=\frac{\text { Earning After Tax }}{\text { Total asset }}
$$

While the ROE calculation is: (Husnan, 2013)

\section{RESULTS AND DISCUSSION}

$$
R O E=\frac{\text { Net Income }}{\text { Equity }}
$$

\section{Research Results}

This research was conducted at mining companies listing on DES (Syariah Securities Register) which consistently report financial statements in 2016-2018. Based on the purposive sampling method, the total sample used in this study is 10 sample companies.

\section{Discussion}

\section{Influence of Corporate Social Responsibility Toward Sustainable Ecnomic Development}

At this time, companies are no longer faced with responsibilities that are grounded in the aspect of economic benefits only, namely the value of the company that is reflected in financial conditions, but also must pay attention to social and environmental aspects, or what is commonly called the Three Bottom Line. The synergy of these three elements is the key to the concept of sustainable development (Wahyuningrum, Noor, \& Wachid, 2014). The CSR program conducted by the company is expected to have a good impact on society from the economic, social and environmental aspects in realizing a sustainable life. 


\section{AFEBI Islamic Finance and Economic Review (AIFER)}

\section{Vol.3 No.2, December 2018}

The first hypothesis proposed states that CSR Disclosure has a significant effect on Sustainable Economic Development. Based on the results of the study the significance value of the CSR variable of $<0.001$ is smaller than 0.005 , the variable Corporate Social Responsibility affects the Sustainable Economic Development. Based on the fit model picture above, the analysis of the influence of Corporate Social Responsibility has a positive relationship to the variable Sustainable Economic Development shown by which has a positive value of 0.33 . Based on these results $\mathrm{H} 1$ is accepted namely the disclosure of Corporate Social Responsibility has a significant influence and positive relation Variable Sustainable Economic Development.

This study supports previous research conducted by (Wahyuningrum, Noor, \& Wachid, 2014) which states that CSR has a significant and simultaneous significant effect between social, economic and environmental variables on increasing community empowerment. And supporting research conducted by (Setyaningrum, 2011) results in showing that all variables used, namely Corporate Social Responsibility Goal, Corporate Social Issues, and Corporate Social Programs significantly have a positive influence on improving people's welfare.

\section{The Effect of Corporate Social Responsibility on Financial Performance.}

The company's main goal is to increase the value of the company, because the value of the company can be said to be good if the financial performance of the company is also good. The company's performance will be ensured sustainable growth if the company pay attention to the economic, social and environmental as sustainability is a balance between the interests of economy, environment and society. With good CSR practices, it is expected that the company's performance will be assessed well by investors. (Mubarok, 2013)

The second hypothesis proposed states that disclosure of corporate social responsibility has a significant effect on financial performance. Based on the research results obtained by the value of the $\mathrm{P}$ value of CSR variables of $<0.001$, the variable Corporate Social Responsibility influences financial performance. Based on the image of the column path coefficients, an analysis of the effect of the Corporate Social Responsibility variable on financial performance variables shows that Corporate Social Responsibility has a positive relationship with the financial performance variable shown by which has a positive value of 0.27 . Based on these results $\mathrm{H} 2$ is accepted namely Disclosure Corporate Social Responsibility has a significant effect and has a positive relationship on financial performance.

This study supports the research of Husnan (2013) giving test results that CSR has a significant effect on Return On Assets (ROA), but does not support other indicators, namely Return On Equity (ROE) which in this study ROE significantly influences and has a relationship positive but it is inversely 
INFLUENCE OF DISCLOSURE CORPORATE SOCIAL RESPONSIBILITY TOWARD SUSTAINABLE ECONOMIC DEVELOPMENT WITH FINANCIAL PERFORMANCE AS AN INTERVENING VARIABLE

proportional to research Husnan (2013) states that CSR has no significant effect on Return On Equity (ROE).

The Influence of Financial Performance as an Intervening Variable between Disclosure Corporate Social Responsibility and Sustainable Economic Development

The third hypothesis proposed states that financial performance as an intervening variable has a positive and significant effect between disclosure of corporate social responsibility and sustainable economic development. Based on the results of study the $\mathrm{p}$ value of the financial performance variable of $<0.001$ smaller than 0.05 , then the financial performance variable as an intervening variable influences the variable Corporate Social Responsibility with Sustainable Economic Development. Based on the column picture path coefficients, analysis of financial performance as an intervening variable between variables Corporate Social Responsibility and Sustainable Economic Development has a positive relationship shown by which is positive at 0.37 , then the financial performance variable as an intervening variable has a positive relationship between variables Corporate Social Responsibility with Sustainable Economic Development. From these results it can be concluded that $\mathrm{H} 3$ is accepted, namely financial performance as an influential intervening variable and has a positive relationship between the variable Corporate Social Responsibility and Sustainable Economic Development.

The relationship of financial performance as a mediating variable (intervening) between the variable Corporate Social Responsibility and Sustainable Economic Development has a significant influence and positive relationship because financial performance indirectly impacts on sustainable Economic Development. In theory the legitimacy of the relationship between the company's interaction with the community. The company's efforts to follow changes to gain legitimacy is a process that is carried out continuously. The process of gaining legitimacy relates to social contracts between those made by the company and various parties in the community. CSR funds that are used by companies indirectly depend on the company's financial performance which in the future the program will impact on community empowerment through CSR programs that are run. This study supports previous research by Wardhani (2013) which results in the effect of CSR disclosure on company value through financial performance and going concern value that has a positive and significant effect. However, this study distinguishes on one of the variables, namely the company's value which is replaced by researchers into Sustainable Economic Development.

\section{CONCLUSIONS AND SUGGESTIONS}

\section{Conclusions}

Based on the results of research and discussion of the effect of disclosure corporate social responsibility on sustainable economic development with 


\section{AFEBI Islamic Finance and Economic Review (AIFER)}

\section{Vol.3 No.2, December 2018}

financial performance as an intervening variable (empirical study of mining companies listed on the Sharia Securities List in 2016-2018) the following conclusions can be drawn:

1. There is a significant influence and positive relationship between the variables corporate social responsibility on sustainable economic development. Based on the results of the study the significance value of CSR variables of $<0.001$ is smaller than 0.005 , the variable Corporate Social Responsibility influences the Sustainable Economic Development. Based on the fit model picture above, the analysis of the influence of Corporate Social Responsibility has a positive relationship with the variable Sustainable Economic Development as indicated by which has a positive value of 0.33 . So it is said that corporate social responsibility has a significant effect and has a positive relationship on sustainable economic development.

2 There is a significant influence and positive relationship between variables corporate social responsibility on financial performance. Based on the research results obtained by the value of the $\mathrm{P}$ value of CSR variables of $<0.001$, the variable Corporate Social Responsibility influences financial performance. Based on the image of the column path coefficients, an analysis of the effect of the Corporate Social Responsibility variable on financial performance variables shows that Corporate Social Responsibility has a positive relationship with the financial performance variable shown by which has a positive value of 0.27 . So it is said that corporate social responsibility influences and has a positive relationship on financial performance.

3 There is a significant influence and positive relationship between financial performance as an intervening variable between the variable corporate social responsibility and sustainable economic development. Based on the results of study the $\mathrm{p}$ value of the financial performance variable of $<0.001$ smaller than 0.05 , then the financial performance variable as an intervening variable influences the variable Corporate Social Responsibility with Sustainable Economic Development. Based on the column picture path coefficients, analysis of financial performance as an intervening variable between variables Corporate Social Responsibility and Sustainable Economic Development has a positive relationship shown by which is positive at 0.37 , then the financial performance variable as an intervening variable has a positive relationship between variables Corporate Social Responsibility with Sustainable Economic Development.

\section{Suggestions}

The suggestions made from the research that has been done are as follows:

1. Academics

a. Find out more about the use of CSR for companies and the public by increasing literature from books, journals and other references. 
INFLUENCE OF DISCLOSURE CORPORATE SOCIAL RESPONSIBILITY TOWARD SUSTAINABLE ECONOMIC DEVELOPMENT WITH FINANCIAL PERFORMANCE AS AN INTERVENING VARIABLE

b. Be more knowledgeable about the broader CSR disclosure indicators because there are many versions related to CSR disclosure indicators

2. Practitioner

a. This research can be used as a comparison for other mining companies in implementing strategies to enhance their activities in the form of CSR and carry out sustainable activities.

b. Companies must further enhance CSR activities by sharing strategies, because in CSR disclosures mining companies only have 2 high categorized companies, namely PT Indo Tambang Raya Megah Tbk and PT Tambang Batubara Bukit Asam (Persero) Tbk

3. Next Researcher

a. For further researchers the company can determine broader criteria both from the type of company and its territory

b. In determining the variables for further research can be more diverse and more numerous such as company value, profitability or others

\section{REFERENCE}

Abdillah, W., \& Hartono, J. (2015). Partial Least Square (PLS) Alternatif Structural Equation Modeling (SEM) dalam Penelitian Bisnis) . Yogyakarta: Penerbit ANDI Yogyakarta.

Adharani, Y. (2017). Penaatan Dan Penegakan Hukum Lingkungan Pada Pembangunan Infrastruktur Dalam Mewujudkan Pembangunan Berkelanjutan ( Studi Kasus Pembangunan PLTU II Di Kecamatan Mundu Kabupaten Cirebon ). Jurnal Ilmu Hukum, 61-83.

Andi, M. (2009). Implementasi CSR Terhadap Kesejahteraan Hidup Masyarakat. JESP.

Arifin, J., \& Wardani, E. A. (2016). Islamic Corporate Social Responsibility Disclosure, Reputasi, dan Kinerja Keuangan:Studi Pada Bank Syariah di Indonesia. Jurnal Akuntansi \& Auditing Indonesia.

Fahmi, I. (2017). Analisis Kinerja Keuangan. Bandung: Penerbit Alfabeta.

Farida, D. N. (2019). Pengaruh Diversitas Gender Terhadap Pengungkapan Sustainibility Development Goals. Jurnal Akuntansi Indonesia, 90.

Helmi. (2011). Hukum Lingkungan Dalam Negara Hukum Kesejahteraan Untuk Mewujudkan Pembangunan Berkelanjutan. Jurnal Ilmu Hukum, 99.

Husnan. (2013). Pengaruh Corporate Social Responsibility (CSR Disclosure) Terhadap Kinerja Keuangan Perusahaan. Diponegoro Journal of Accounting. 


\section{AFEBI Islamic Finance and Economic Review (AIFER)}

\section{Vol.3 No.2, December 2018}

Kusuma, A. B. (2012). Asosiasi Pengungkapan CSR dan Kinerja Keuangan Pada Perusahaan Peraih Penghargaan Indonesia Sustainability Reporting Award (ISRA) Periode . Jurnal Akuntansi UNESA .

Kusuma, A. B. (2012). Asosiasi Pengungkapan CSR dan Kinerja Keuangan Pada Perusahaan Peraih Penghargaan Indonesia Sustainability Reporting Award (ISRA) Periode 2011 dan Terdaftar Di Bursa Efek Indonesia (BEI) 20112012. Jurnal Akuntansi UNESA.

Lako, A. (2011). Dekonstruksi CSR \& Paradigma Reformasi Bisnis \& Akuntansi. Jakarta: Penerbit Airlangga.

Mertasari, N. L., \& Suaryana, I. G. (2013). Pengaruh Pengungkapan CSR Terhadap Kinerja Keuangan Dengan Kepemilikan Asing Sebagai Variabel Moderator. e-jurnal Akuntansi Universitas Udayana, 251.

Mubarok, F. K. (2013). Pengaruh Corporate Social Responsibility dan Profitabilitas terhadap Nilai Perusahaan (Studi Pada Perusahaan yang Listing di Jakarta Islamic Index Tahun 2009-2011). Undergraduated (S1) Thesis IAIN Walisongo, 96.

Putra, A. D. (2017, November 30). Kompas.com. Retrieved from Pemda DIminta Tentukan Fokus Dalam Pemanfaatan Dana CSR: https://ekonomi.kompas.com/read/2017/11/30/124205926/pemda-dimintatentukan-fokus-dalam-pemanfaatan-dana-csr.

Rachman, F. F. (2017, Juli 17). Republika.co.id. Retrieved from Orang Miskin Terbanyak di Jawa, Presentase Tersebar di Maluku-Papua: https://finance.detik.com/berita-ekonomi-bisnis/d-3563157/orang-miskinterbanyak-dijawapersentaseterbesar-di-maluku-papua?

$\mathrm{Ga}=2.81241054 .814418660 .1567221724$

Rakhiemah, A., \& Agustia, D. (2009). Pengaruh Kinerja Lingkungan terhadap Corporate Social Responsibility (CSR) Disclosure dan Kinerja Finansial Perusahaan Manufaktur yang Terdaftar di Bursa Efek Indonesia. Simposium Nasional Akuntansi XII, (p. 9). Palembang.

Retnaningsih, H. (2015, Desember 23). Permasalahan Corporate Social Responsibility(CSR) Dalam Rangka Pemberdayaan Masyarakat. 2015, p. 177.

Setyaningrum, D. A. (2011). Pengaruh Implementasi Corporate Social Responsibility Terhadap Kesejahteraan Hidup Masyarakat (Studi Kasus pada PT. APAC INTI CORPORA, Bawen). Semarang: Fakultas Ekonomi dan Bisnis Universitas Diponegoro Semarang.

Sulhan, M., \& Halimah, D. N. (2013). Pengaruh Kinerja Keuangan Perbankan Berdasarkan Analisis Camels Terhadap Harga Saham Dengan Csr Sebagai Variabel Intervening. Iqtisodhuna, 192. 
INFLUENCE OF DISCLOSURE CORPORATE SOCIAL RESPONSIBILITY TOWARD SUSTAINABLE ECONOMIC DEVELOPMENT WITH FINANCIAL PERFORMANCE AS AN INTERVENING VARIABLE

Suparno, P. (2012). "Peningkatan Mutu Pendidikan MIPA Untuk Menunjang Pembangunan Berkelanjutan (Sustainable Development",. SEMNAS FMIPA UNDHIKSA. Yogyakarta: FMIPA UNDHIKSA.

Wahyuningrum, Y., Noor, I., \& Wachid, A. (2014). Pengaruh Program Corporate social responsibility Terhadap Peningkatan Pemberdayaan Masyarakat. (Studi Pada Implementasi CSR PT. Amerta Indah Otsuka Desa Pacarkeling Kecamatan Kejayan Kabupaten Pasuruan). Jurnal Administrasi Publik (JAP).

Wardhani, R. S. (2013). Pengaruh CSR Disclosure Terhadap Nilai Perusahaan dengan Kinerja Keuangan Sebagai Variabel Intervening (Studi Kasus Perusahaan Manufaktur yang Terdaftar di BEI). Fakultas Ekonomi Universitas Bangka Belitung, JEAM.

Wulandari, R., \& Yolanda, F. (2019, September 10). Republika.co.id. Retrieved from Masuk 11 Perusahaan Terbaik, Adaro Terus Pacu Kinerja: https://republika.co.id/berita/pxlezo370/masuk-11-perusahaan-terbaikadaro-terus-pacu-kinerja 